\title{
ANALISIS KELAYAKAN USAHA POLA PEMELIHARAAN SEMI INTENSIF KERING ITIK PETELUR DARA (FASE GROWER) UMUR DUA BULAN DI KABUPATEN LIMAPULUH KOTA
}

\author{
Ulva Mohtar Lutfi ${ }^{1}$, Riva Hendriani ${ }^{1}$, Ali Suyono ${ }^{1}$, Toni Malvin ${ }^{1}$ dan Mukhlis ${ }^{1}$ \\ ${ }^{1}$ Politeknik Pertanian Negeri Payakumbuh \\ ulvamohtar@gmail.com
}

\begin{abstract}
ABSTRAK
Pola pemeliharaan itik petelur di Provinsi Sumatera Barat khususnya di Kabupaten Limapuluh Kota sebagian besar menggunakan model kombinasi dikandangkan dan penggembalaan di sawah sehingga peternak sering berpindah-pindah tempat untuk mencari lokasi sawah yang sedang musim panen. Seiring tuntutan efisiensi pemeliharaan dan keterbatasan lahan diperlukan alternatif pola pemeliharaan itik dengan analisis kelayakan usahanya.

Tujuan penelitian ini adalah analisis kelayakan usaha pola pemeliharaan semi intensif kering itik petelur dara (fase grower) umur dua bulan di Kabupaten Limapuluh Kota. Metode analisis kelayakan usaha dengan pendekatan rasio $R / C$ (revenue/cost) pada model penerapan pola pemeliharaan semi intensif kering itik petelur dara (fase grower) sebanyak 102 ekor umur satu hari sampai dua bulan dengan kandang panggung tertutup dan kandang terbuka sistem kering tanpa kolam pemandian dengan pagar pembatas di Kabupaten Limapuluh Kota. Pakan yang diberikan adalah pakan komplit pabrikan umur 0-14 hari dilanjutkan pakan adukan umur 15-60 hari.

Hasil penelitian menunjukkan komponen biaya tetap berupa biaya penyusutan kandang, sewa tanah dan peralatan sebesar Rp 47.800,00; biaya listrik dan air sebesar Rp 12.000,00 biaya variabel berupa pembelian bibit DOD (Day Old Duck) untuk 102 ekor sebesar Rp 620.000,00 ; biaya pakan dan obat-obatan sebesar Rp 2.001.640,00; biaya sekam dan jerami untuk alas kandang sebesar $R p$ 15.000,00 ; biaya tenaga kerja sebesar Rp 120.000,00. Pendapatan yang diperoleh dari penjualan itik petelur grower umur dua bulan (mortalitas 1\%) sebesar $R p$ 3.232.000,00 dan penjualan kotoran itik sebesar $R p$ 28.000,00. Total biaya sebesar $R p$ 2.816.440,00 dengan total pendapatan sebesar $R p$ 3.260.000,00 sehingga didapatkan rasio $R / C$ sebesar 1,16.

Kesimpulan dari penelitian ini adalah pola pemeliharaan semi intensif kering itik petelur dara (fase grower) umur dua bulan diperoleh : biaya tetap sebesar 2,1\% dari total biaya, biaya bibit sebesar $22 \%$ dari total biaya, biaya pakan sebesar 71,1\% dari total biaya, biaya alas kandang sebesar 0,5\% dari total biaya dan biaya tenaga kerja sebesar 4,3\% dari total biaya. Rasio R/C sebesar 1,16 sehingga layak untuk dikembangkan karena lebih tinggi dari bunga bank.
\end{abstract}

Kata kunci: kelayakan usaha, itik petelur dara, biaya pemeliharaan, rasio $R / C$

\section{PENDAHULUAN}

Pola pemeliharaan itik petelur di Provinsi Sumatera Barat khususnya di Kabupaten Limapuluh Kota sebagian besar menggunakan model kombinasi dikandangkan dan penggembalaan di sawah sehingga peternak sering berpindah-pindah tempat untuk mencari lokasi sawah yang sedang musim panen. Peternakan itik dengan sistem penggembalaan dijalankan oleh $2 \%$ petani peternak integrasi pertanian peternakan terpadu padi itik di Kabupaten limapuluh Kota. Interaksi tanaman padi pada ternak itik adalah padi menyiapkan makanan pada ternak itik pada saat setelah panen yaitu dengan cara melepas itik di sawah yang telah dipanen dengan tujuan itik memakan sisa-sisa buah padi dan setelah pasca panen makanan itik bias didapat dari kulit buah padi yaitu dedak. (Lutfi, dkk., 2017). 
Umumnya di Propinsi Sumatera Barat itik masih dipelihara secara tradisional dengan penggembalaan secara berpindah-pindah. Dengan semakin sempitnya areal penggembalaan dan banyaknya resiko kematian ternak akibat keracunan pestisida maka pemeliharaan sistim gembala ini makin terancam. Salah satu usaha yang dirasa mampu mengatasinya adalah melakukan pemeliharaan itik secara intensif, atau semi intensif (Ermidias, 2016). Pergeseran pola/sistem budidaya itik ini disebabkan oleh berkurangnya tempat penggembalaan antara lain karena makin intensifnya penanaman padi di sawah, konversi atau alih fungsi lahan persawahan menjadi daerah pemukiman dan industri. Selain itu juga karena meningkatnya kesadaran peternak dalam mencegah dan menularnya penyakit unggas seperti Avian Influenza (Permentan no. 35 tahun 2007). Seiring tuntutan efisiensi pemeliharaan dan keterbatasan lahan diperlukan alternatif pola pemeliharaan itik semi intensif kering dengan penggunaan lahan yang lebih efisien dan tidak berpindah-pindah tempat. Berdasarkan hal tersebut diatas, tujuan penelitian ini adalah analisis kelayakan usaha pola pemeliharaan semi intensif kering itik petelur dara (fase grower) umur dua bulan di Kabupaten Limapuluh Kota.

\section{METODE PENELITIAN}

Penelitian dilaksanakan pada lokasi kandang peternak itik di Nagari Solok Bio-Bio Kecamatan Harau Kabupaten Limapuluh Kota, yang dimulai pada Juni - Agustus 2018. Alat yang digunakan berupa kandang itik model panggung dan area penggembalaan berpagar waring, tempat pakan, tempat minum, lampu, timbangan, software formulasi pakan unggas dan tirai plastik. Bahan yang digunakan berupa : DOD (Day Old Duck) itik petelur betina 102 ekor yang didatangkan dari breeding farm di Medan Sumatera Utara, Pakan komersial crumble dengan protein 20-23\%, pakan adukan yang terdiri konsentrat itik petelur, jagung, dedak dan kapur, sekam, koran bekas, jerami, sekop, hand sprayer dan desinfektan.

Analisa kelayakan usaha menggunakan rasio R/C, secara matematis dapat ditulis:

$\mathrm{R} / \mathrm{C}$ ratio $=\mathrm{TR} / \mathrm{TC}$

Dimana:

$\mathrm{TR}=$ Total revenue

$\mathrm{TC}=$ Total cost

Nilai rasio R/C selanjutnya dibandingkan dengan suku bunga bank deposito yang berlaku (Mukhlis, 2018).

\section{HASIL DAN PEMBAHASAN}

Hasil penelitian menunjukkan komponen biaya tetap berupa biaya penyusutan kandang, sewa tanah dan peralatan sebesar Rp 47.800,00. Kandang uang digunakan berupa kandang panggung semipermanen yang berbahan dasar kayu kelapa dan area bermain berpagar waring. Hal ini sesuai dengan Permentan nomor 35 tahun 2007 tentang Good 
Farming Practice beternak itik yang menyatakan bangunan dan alas kandang terbuat dari bahan yang ekonomis, kuat dan menjamin kemudahan pemeliharaan, pembersihan dan desinfeksi kandang.

Biaya listrik dan air sebesar Rp 12.000,00 diperoleh dari kebutuhan bohlam lampu sebesar 75 watt untuk pemanas pada 2 minggu pertama yang dinyalakan pada malam hari saja dan air yang digunakan adalah air sumur dengan pengambilan air secara manual.

Biaya variabel berupa pembelian bibit DOD (Day Old Duck) untuk 102 ekor sebesar Rp 620.000,00 sudah termasuk ongkos kirim dari Medan ke Kabupaten Limapuluh Kota. Harga DOD fluktuatif dari waktu ke waktu, harga Rp 620.000,00/boks 102 ekor termasuk relatif tinggi sebelumnya dikisaran harga Rp 500.000,00/boks. Bibit yang dipilih adalah tipe itik kering sesuai dengan ciri-ciri bibit yang baik. Potensi genetik bibit merupakan salahsatu faktor yang penting dalam menunjang keberhasilan usaha ternak itik (Khatun, et al., 2012).

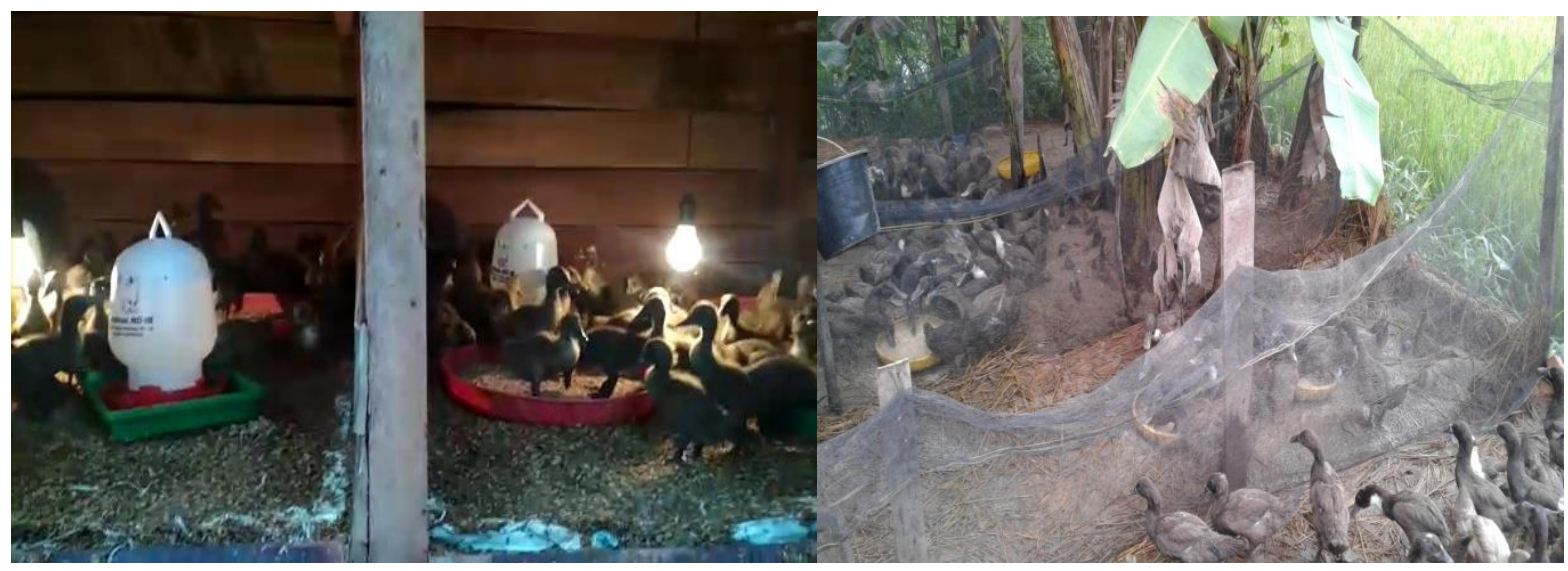

Biaya pakan dan obat-obatan sebesar Rp 2.001.640,00 merupakan komponen biaya terbesar yang didapatkan dari pakan crumble komersial yang diberikan pada umur 1-14 hari dan dilanjutkan umur 15-60 hari dengan pakan adukan yang terdiri dari dedak, konsentrat itik, kapur dan jagung giling. Hal ini sesuai dengan pendapat Ermadias (2011) yang menyatakan biaya pakan merupakan biaya terbesar yaitu sekitar 60-70\% dari biaya produksi yang dikeluarkan pada usaha ternak itik. Kandungan Protein kasar dan energi dari ransum disesuaikan dengan standar kebutuhan itik fase starter dan grower. Mutu ransum pakan harus sesuai dengan ketentuan yang berlaku yaitu SNI 01-3908-1995 untuk Pakan Meri (Duck Starter) dengan protein kasar 18-20\% dan Energi metabolism 3000 kkal; SNI 01-3909-1995 untuk Pakan Itik Petelur Dara (Duck Grower) protein kasar 15\% dan Energi metabolism 2700 kkal (Permentan nomor 35 tahun 2007). Ransum yang digunakan pada penelitian ini pada fase duck starter dengan kandungan protein kasar 18-22\% dan Energi metabolism 3000 kkal, sedangkan untuk fase Itik Petelur Dara (Duck Grower) protein kasar 15,04\% dan Energi metabolism 2477 kkal yang masih dalam kisaran mendekati standar. 
Komponen biaya berikutnya adalah biaya sekam, koran bekas dan jerami untuk alas kandang sebesar Rp 15.000,00 dan biaya tenaga kerja sebesar Rp 120.000,00. Biaya tenaga kerja diperoleh dari waktu yang digunakan untuk memberi pakan dan mengganti air minum perhari untuk 102 ekor itik yang dipelihara dikali dengan HKO (Harga Kerja Orang) sebesar Rp. 70.000,00 per hari (7 jam).

Pendapatan yang diperoleh dari penjualan itik petelur grower umur dua bulan (mortalitas 1\%) sebesar Rp 3.232.000,00 dengan menjual pada pedagang pengepul yang datang ke kandang dengan harga rata-rata 32.000,00 per ekor. Pembeli merasa puas dengan kondisi itik yang bersih dan sehat karena dipelihara dengan sistem kering serta dengan recording pemeliharaan yang baik. Pendapatan berikutnya diperoleh dari penjualan kotoran itik sebesar Rp 28.000,00. Total biaya sebesar Rp 2.816.440,00 dengan total pendapatan sebesar Rp 3.260.000,00 sehingga didapatkan rasio R/C sebesar 1,16.

\section{KESIMPULAN}

Kesimpulan dari penelitian ini adalah pola pemeliharaan semi intensif kering itik petelur dara (fase grower) umur dua bulan diperoleh : biaya tetap sebesar 2,1\% dari total biaya, biaya bibit sebesar $22 \%$ dari total biaya, biaya pakan sebesar $71,1 \%$ dari total biaya, biaya alas kandang sebesar $0,5 \%$ dari total biaya dan biaya tenaga kerja sebesar 4,3\% dari total biaya. Rasio R/C sebesar 1,16 sehingga layak untuk dikembangkan karena lebih tinggi dari bunga bank.

\section{DAFTAR PUSTAKA}

Ermadias. 2016. Teknologi Budidaya Itik Di Lahan Pekarangan. Balai Penkajian Teknologi Pertanian Sumatera Barat. Jl. Raya Padang - Solok km 40 Sukarami, Solok 27366, Indonesia

Khatun, M., N. Islam, A. A. Bhuyan ,M. N. Hasan and M. S. Islam. 2012. Performance Of BLRI Developed Native Duck Under Farmers Condition With Supplementary Feeding. Bangladesh Journal of Livestock Research > Vol 19, No 1-2 (2012)

Mukhlis. 2018. Analisis Usahatani Dan Kelayakan Usahatani Sistem Integrasi Padi-Sapi Berbasis Skala Usaha Di Kabupaten Lima Puluh Kota. Laporan Akhir Penelitian Hibah Doktor. Pusat Penelitian dan Pengabdian Masyarakat (P3M) Politeknik Pertanian Negeri Payakumbuh.

Lutfi, U.M., Suyono, A. dan Hendriani, R. 2017. Model Pengembangan Pertanian Terpadu Untuk Menunjang Pengembangan Wilayah Di Kabupaten Lima Puluh Kota. Laporan tahun 1 Penelitian Terapan Unggulan Perguruan Tinggi (PTUPT). Pusat Penelitian dan Pengabdian Masyarakat (P3M) Politeknik Pertanian Negeri Payakumbuh.

Permentan nomor 35. 2007. Permentan no. 35/Permentan/2007 tentang Pedoman Cara Beternak Itik Yang Baik (Good Farming Practice). Perundangan.pertanian.go.id. 